\title{
Perancangan Sistem Informasi Penjualan Berbasis Web pada Toko Campus Mart Unimuda Sorong dengan PHP Dan MySql
}

\author{
Winarti, Muhammad Ihsan, Novita Wulandari \\ Universitas Pendidikan Muhammadiyah Sorong \\ $\underline{\text { winartinarti0641@gmail.com }}$
}

\begin{abstract}
Abstrak: Tujuan dilakukan penelitian ini adalalah untuk merancang sebuah sistem informasi dan pemesanan produk berbasis web. Desain penelitian yang digunakan adalah pengembangan (research and development/R\&D). dengan pendekatan studi kasus pada Toko Campus Mart UNIMUDA Sorong. Metode pengembangan sistem informasi penjualan berbasis web yang dibuat sekarang menggunakan metode prototype, dan alat bantu pengembangan sistem berupa flowmap, diagram konteks, DFD, dan alat perancangan database yang diusulkan berupa ERD. Penulis mengunakan PHP, HTML, CSS dan Notepad ++ untuk database mengunakan $\mathrm{MySqL}$, berdasarkan Hasil penelitian menunjukan bahwa perancangan sistem informasi penjualan berdasarkan seluruh hasil penelitian dapat disimpulkan bahwa indikator aspek program dengan rerata 3,5 dan presentase 87,5\%, indikator aspek content dengan rerata 3,6 dan presentase 91,25\% dan indikator aspek pengguna dengan rerata 3,6 dan presentase 87,5 bahwa aspek program dinyatakan sangat valid. Maka aplikasi dapat digunakan atau valid menurut validator untuk diuji coba ketahap berikutnya, berupa uji coba kelompok kecil dan uji coba kelompok besar. menunjukkan bahwa secara keseluruhan indikator pengguna aplikasi praktis memperoleh rerata dengan nilai 3,4 dan presentase $86 \%$ dengan kategori sangat praktis dan secara keseluruhan indikator pengguna aplikasi efektif memperoleh rerata3,4 dan presentase $85 \%$ dengan kategori sangat efektif. Dapat disimpulkan bahwa sistem informasi penjualan dapat digunakan dengan praktis dan efektif dalam proses penjualan di Toko Campus Mart UNIMUDA Sorong.

Kata kunci : Sistem, Informasi, Penjualan, Web, Toko, Campus Mart, prototype.
\end{abstract}

Abstrak: The purposed of this research was the designing an information system and booking product web-based. The research design used research and development ( $R$ \& D) with approach of case research in Campus Mart of UNIMUDA Sorong. The approach was structured and the development of sales information system web-based used prototype method, the auxiliary tool of system development was flowmap, Contexs diagram, DFD, and the tool of designing database was ERD. The researcher used PHP, HTML, CSS and Notepad++, for the databed used MySqL.Based on the research result in designing sales information system, it represented that the indicator of program aspectwith an average 3,5 persentage $87,5 \%$, then the indicator of content aspect with an average 3,6 percentage $91,25 \%$ and the indicator of use aspect with an average 3,6 percentage $87,5 \%$. It meant that the program aspect was very valid, and the application can be used or according to validator it was valid for trial to the next step. The next step was small-scale trial and large-scale trial. It 
represented that all in all, the indicator of practical application user acquired an average value 3,4 with percentage $86 \%$ in very practical category. Then, all in all, the indicator of effective application user totally acquired an average value 3,4 with percentage $85 \%$ in very effective category. It can be conclude that sales information system can be used practically and effectively in sales process of Campus Mart of UNIMUDA Sorong

Keywords: Sales, Information, System, Web, Store, Campus Mart, prototype.

\section{Pendahuluan}

Di era globalisasi perkembangan sistem informasi saat ini, banyak sistem informasi pada organisasi yang ingin mencapai tahap sistem informasi secara cepat, relevan dan akurat. sekumpulan prosedur atau tahapan yang terdiri atas komponen atau elemen yang saling berhubungan untuk mencapai tujuan tertentu (Ramadhani, I. A, 2018). Pesatnya pertumbuhan ilmu pengetahuan teknologi khususnya di bidang komputer disetiap aspek kehidupan dan penggunaan teknologi komputer dan teknologi komunikasi yang menghasilkan sebuah penggabungan sistem informasi yang saat ini mudah untuk di akses tanpa adanya batasan waktu dan jarak dengan menggunakan jaringan internet. Model penjualan atau bisnis ikut terpengaruh dari perkembangan ilmu pengetahuan teknologi tersebut, terlebihnya dengan pesatnya pertumbuhan pengguna internet di berbagai belahan dunia khususnya negara berkembang. Salah satu bisnis yang menjadi trend terbaru di masyarakat ini adalah dalam bidang belanja online. Sejauh ini Toko Campus Mart UNIMUDA Sorong masih melakukan promosi dan penjualan melalui mulut ke mulut atapun berbentuk brosur, sehingga jangkauan promosi dan penjualan masih terbatas dan belum bisa meluas ke beberapa daerah. Kendala lain yang di alami oleh Toko Campus Mart UNIMUDA Sorong yaitu persaingan yang ketat, hal itu membuat Toko Campus Mart UNIMUDA Sorong harus mempunyai strategi pemasaran yang berbeda dari pesaingnya. Untuk itu di butuhkan sebuah aplikasi berbasis web yang mampu memberikan informasi mengenai produk kepada pelanggan dengan cepat melalui internet. Berdasarkan latar belakang di atas, maka penulis merancang system informasi penjualan, untuk mempermudah pengguna dalam transaksi kapan dan dimana saja. berdasarka latar belakang diatas penulis tertarik mengangkat judul "Perancangan Sistem Informasi Penjualan Berbasis Web Pada Toko Campus Mart UNIMUDA Sorong Dengan PHP Dan MYSQL”.

\section{Metode Penelitian}

Jenis penelitian yang digunakan adalah jenis penelitian dan pengembangan (research and development/ R\&D). Penelitian dan Pengembangan atau Research and Development (R\&D) adalah suatu proses atau langkah-langkah untuk mengembangkan suatu produk baru atau menyempurnakan produk yang telah ada sehingga dapat dipertanggungjawabkan. Produk tersebut tidak selalu berbentuk hardware software tetapi program komputer untuk pengelolahan data, pembelajaran di kelas, perpustakaan atau laboratorium, pelatihan, bimbingan, evaluasi dan manajemen (Winarni, 2018). Tahap penelitian dalam perancangan sistem ini peneliti akan menggunakan model pengembangan Prototyping. Prototyping merupakan teknik pengembangan sistem yang menggunakan 
Prortotype untuk menggambarkan sistem sehingga pengguna sistem mempunyai gambaran pengembangan sistem yang akan dilakukannya. (Sri Mulyani, 2016). Pengujian sistem menggunakan black box testing. Black boxtesting berfokus pada spesifikasi fungsional pada spesifikasi fungsional dari perangkat lunak. Sistem ini akan di validasi oleh 2 orang pakar yang terdiri dari 1 orang ahli system dan 1 orang yang memvalidasi angket. Tester dapat mendefinisikan kumpulan kondisi input dan melakukan pengetesan pada spesifikasi fungsional program yang cenderung menemukan fungsi yang tidak benar atau tidak ada, kesalahan antarmuka (interface errors), kesalahan pada struktur data dan akses basis data, kesalahan performansi (performance errors), dan kesalahan inisialisasi dan terminasi. Proses pengujian peneliti membagi 2 tahap yaitu: Uji coba kelompok kecil dan Uji coba diperluas.

\section{Hasil dan Pembahasan}

Hasil pengembangan sistem informasi penjualan berbasis web pada Toko Campus Mart UNIMUDA Sorong menggunakan model pengembangan prototyping yag terdapat pada metode pengembangan SDLC (system development life cycle), meliputi langkah analisis kebutuhan, perancangan, membangun prototype, evaluasi, perubahan perancangan.

a. Prototype Menu Login Admin

untuk menggunakan menu yang ada perlu melakukan login dengan cara input nama dan password untuk admin seperti Gambar 1:

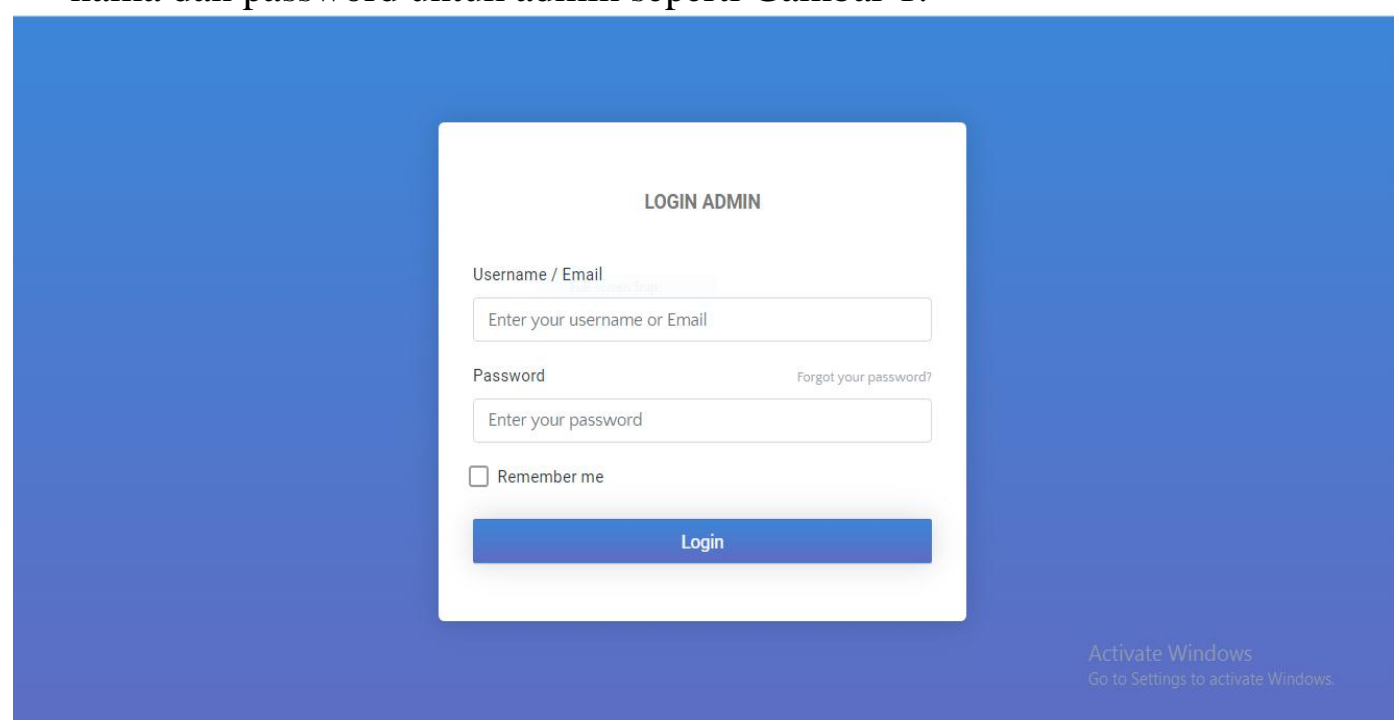

Gambar 1 Prototype Menu Login Admin

\section{b. Prototype Menu Data Pelanggan}

Pada menu data pelanggan berfungsi untuk melihat data pelanggan yangberhasil melakukan register atau daftar pelanggan seperti Gambar 2: 


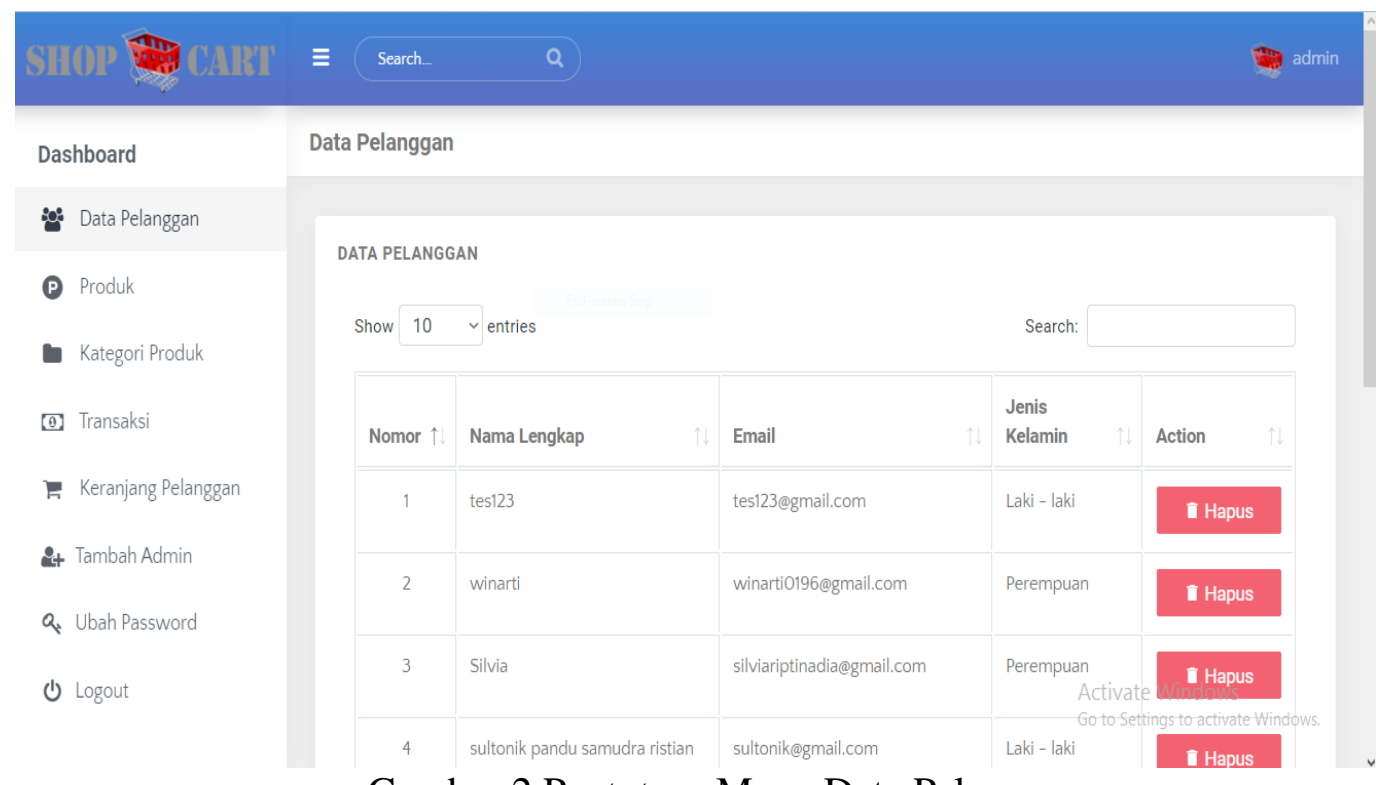

Gambar 2 Prototype Menu Data Pelanggan

\section{c. Prototype Menu Cari Data Pelanggan}



Gambar 3 Prototype Menu Cari Data Pelanggan 


\section{d. Prototype Menu data produk}

Menu produk berfungsi untuk melihat dan menghapus data produk yang sudah di input seperti Gamba 4.

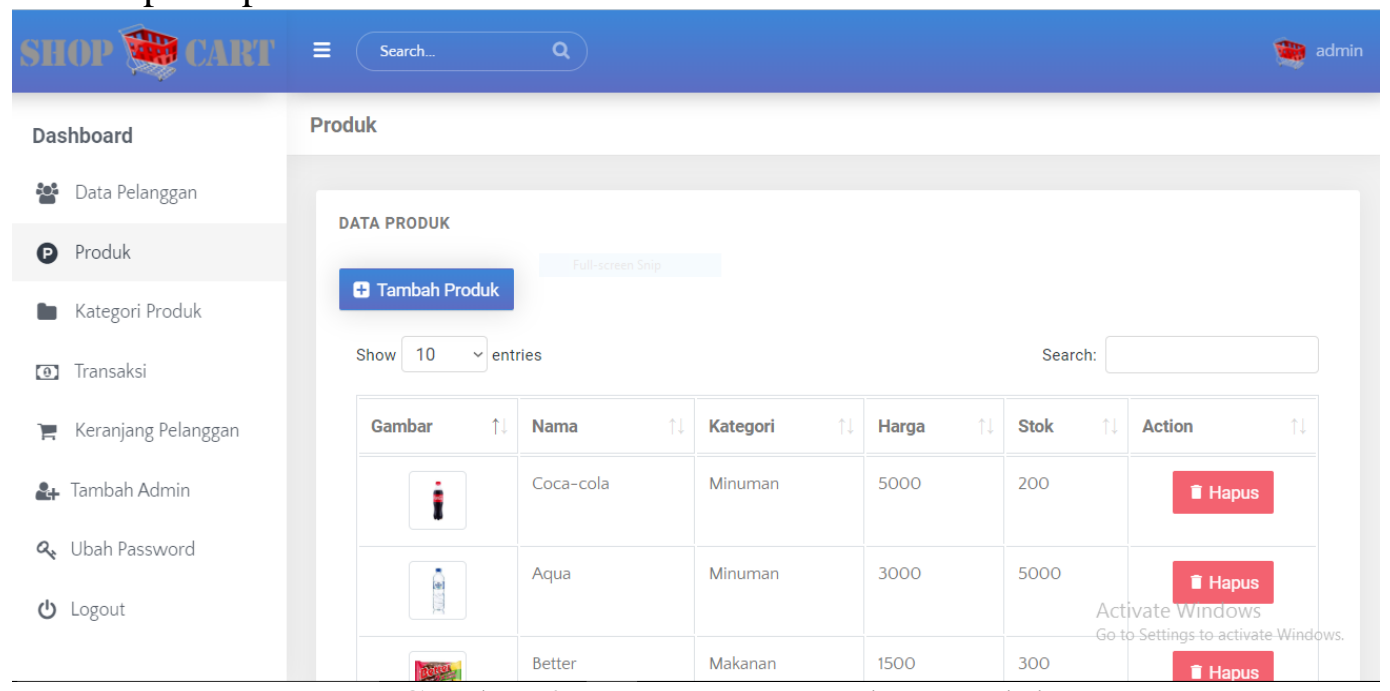

Gambar 4 Prototype Menu data produk

\section{e. Prototype Menu tambah produk}

Tambah produk berfungi untuk melakukan proses penginputan data produk dengan cara klik tombol tambah produk dilanjutkan dengan input nama produk, kategori, harga, stok, gambar, dan deskripsi produk lalu klik simpan seperti Gamba 5.

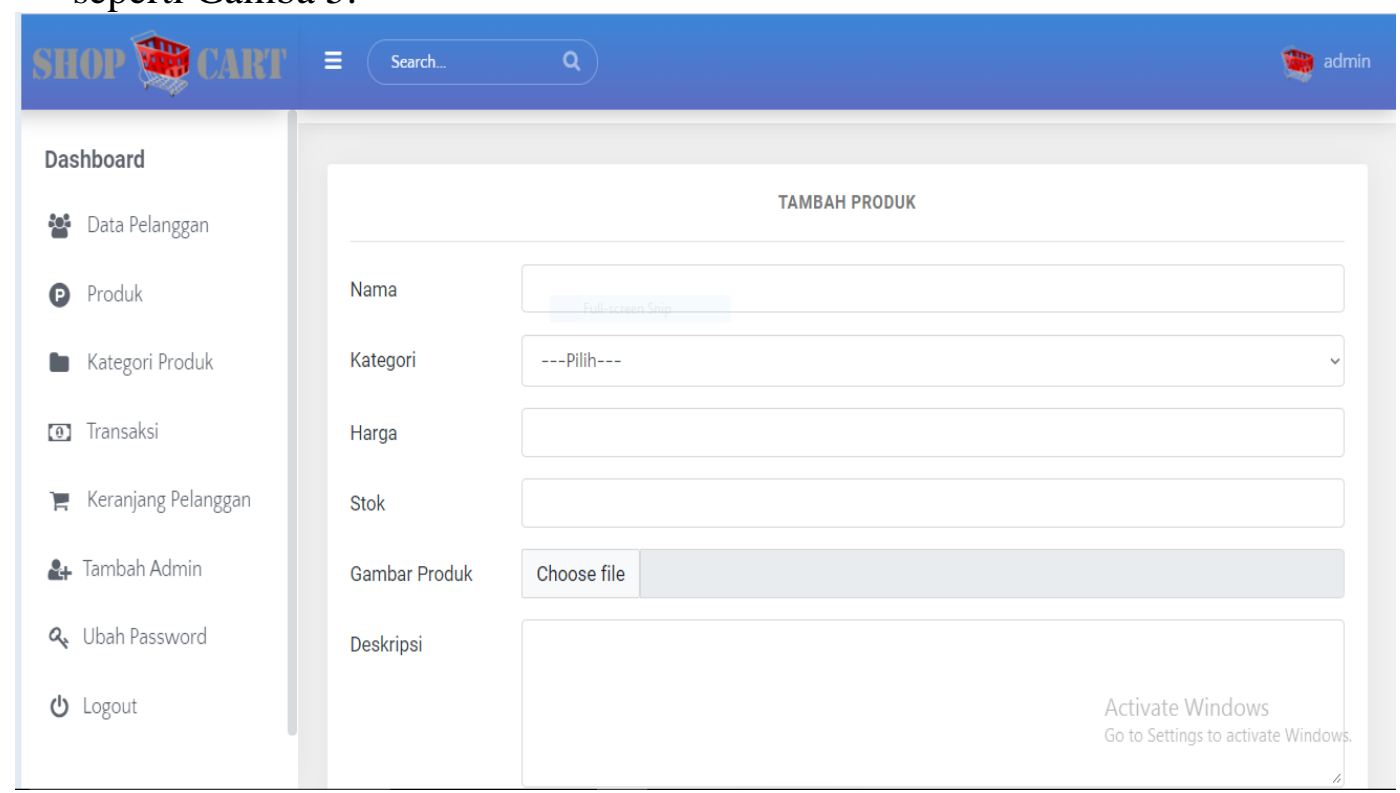

Gambar 5 Prototype Menu tambah produk

Uji coba

Uji coba lapangan melibatkan 30 pelanggan Toko Campus Mart UNIMUDA Sorong. Uji coba kelompok besar terdiri dari 6 indikator yaitu : (1) mudah dipahami, (2) mudah digunakan, (3) memudahkan dalam proses daftar pelanggan (register), (4) 
memudahkan dalam proses pemilihan produk, (5) memudahkan dalam proses pembelian produk, (6) memberikan informasi produk yang dijual.

1) Indikator Kualitas Aplikasi/Sistem

Tabel 1 Indikator Kualitas Aplikasi/Sistem

\begin{tabular}{|c|c|c|c|c|}
\hline No & Aspek yang dinilai & Rerata & Presentase & Keterangan \\
\hline $\mathbf{1}$ & Mudah dipahami & 3,4 & $85 \%$ & Sangat baik \\
\hline 2 & Mudah digunakan & 3,65 & $91,25 \%$ & Sangat baik \\
\hline 3 & $\begin{array}{l}\text { Mudah dalam proses daftar } \\
\text { pelanggan (register) }\end{array}$ & 3,65 & $91,25 \%$ & Sangat baik \\
\hline 4 & $\begin{array}{l}\text { Mumudahkan dalam proses } \\
\text { pemilihan produk }\end{array}$ & 3,8 & $95 \%$ & Sangat baik \\
\hline 5 & $\begin{array}{l}\text { Memudahkan dalam proses } \\
\text { pembelian produk }\end{array}$ & 3,75 & $93,73 \%$ & Sangat baik \\
\hline 6 & $\begin{array}{c}\text { Memberikan iformasi produk } \\
\text { yang dijual }\end{array}$ & 3,6 & $90 \%$ & Sangat baik \\
\hline & Keseluruhan Indikator & 3,6 & $91 \%$ & Sangat baik \\
\hline
\end{tabular}

Data indikator kualitas aplikasi/sistem yang ditunjukkan pada tabel 4.13 diatas menunjukkan keseluruhan kualitas sistem memiliki rerata 3,6 dan presentase $91 \%$ berada dalam kategori sangat baik, dapat disimpulkan bahwa keseluruhan indikator kualitas aplikasi/sistem sudah dapat dikatan sangat baik. Uji coba dilakukan dengan cara menunjukkan kerja sistem informasi penjualan. Pada uji coba ini semua responden dipersilahkan mengoperasikan dan bertanya tentang sistem informasi penjualan yang di uji coba agar semua responden paham kualitas aplikasi/sistem yang diuji. Tingkat rerata skor penilaian idikator kualitas sistem/aplikasi pada uji kelompok besar dapat dilihat pada Gambar 6.

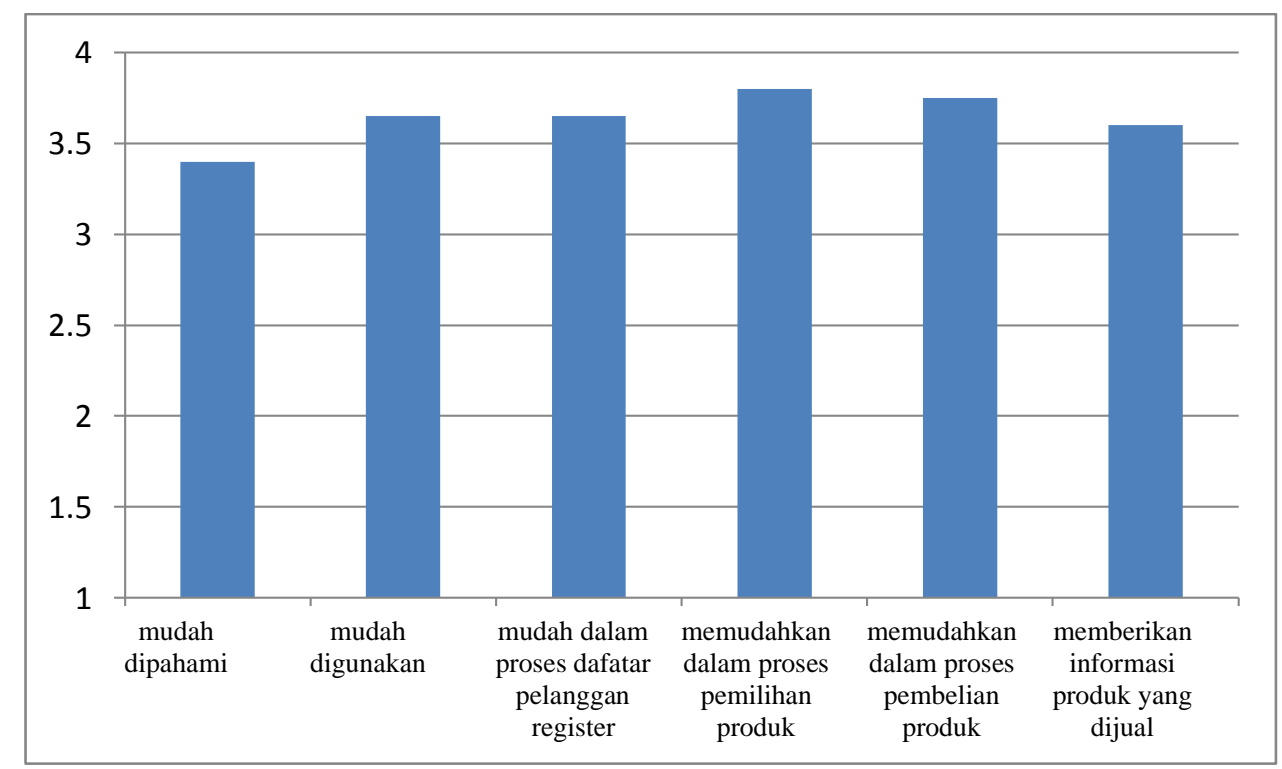

Gambar 6 Grafik Penilaian Kualitas Sistem Kelompok Besar 
2) Indikator navigasi

Tabel 2 Indikator Navigasi

\begin{tabular}{ccccc}
\hline No & Aspek yang dinilai & Rerata & Presentase & Keterangan \\
\hline $\mathbf{1}$ & Kemudahan memilih menu & 3,35 & $83,75 \%$ & Sangat baik \\
$\mathbf{2}$ & Kemudahan pengunaan menu & 3,5 & $87,5 \%$ & Sangat baik \\
$\mathbf{3}$ & Ada peringatan jika & 3,5 & $87,5 \%$ & Sangat baik \\
& melakukan kesalahan login & & & \\
$\quad$ dan input data & & & Sangat baik \\
$\mathbf{4}$ & Kemudahan meng-input data & 3,55 & $88,75 \%$ & \\
$\quad$ menghapus data & & & Sangat baik \\
\hline & Keseluruhan Indikator & $\mathbf{3 , 4}$ & $\mathbf{8 4 , 3 7 \%}$ & \\
\hline
\end{tabular}

Pada Tabel 2 menunjukkan bahwa secara keseluruhan indikator memperoleh rerata 3,4 dan presentase 84,37\% dengan kategori sangat baik. Dapat disimpulkan berdasarkan hasil keseluruhan indikator navigasi bahwa navigasi pada sistem informasi penjualan sesuai dengan kebutuhan yang telah diuji coba kelompok besar dan sudah dapat digunakan diToko Campus UNIMUDA Sorong. Tingkat rerata skor penilaian indicator navigasi pada uji coba kelompok besar dapat dilihat pada Gambar 7

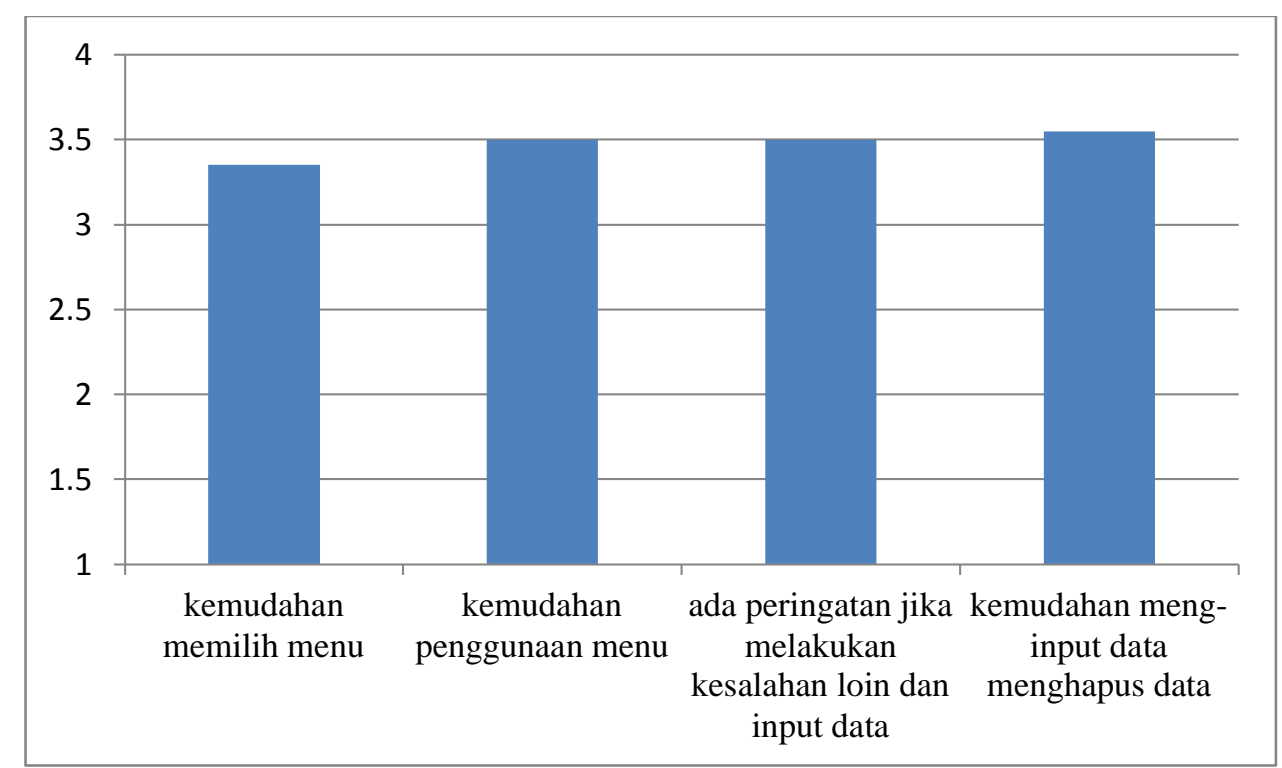

Gambar 7 Grafik Penilaian Navigasi Sistem Kelompok Besar 
3) Indikator penggunaan aplikasi (praktis)

Tabel 3 Indikator Penggunaan Aplikasi (Praktis)

\begin{tabular}{|c|c|c|c|c|}
\hline No & Aspek yang dinilai & Rerata & Presentase & Keterangan \\
\hline $\mathbf{1}$ & $\begin{array}{c}\text { Penggunaan aplikasi secara } \\
\text { bersamaan }\end{array}$ & 3,3 & $82,5 \%$ & $\begin{array}{l}\text { Sangat } \\
\text { praktis }\end{array}$ \\
\hline 2 & $\begin{array}{l}\text { Pengunaan aplikasi } \\
\text { mengefisienkan waktu }\end{array}$ & 3,45 & $86,25 \%$ & $\begin{array}{l}\text { Sangat } \\
\text { praktis }\end{array}$ \\
\hline 3 & $\begin{array}{l}\text { Penggunaa aplikasi } \\
\text { mengefisienkan tempat } \\
\text { pembelian }\end{array}$ & 3,7 & $92,5 \%$ & $\begin{array}{l}\text { Sangat } \\
\text { praktis }\end{array}$ \\
\hline 4 & $\begin{array}{l}\text { Penggunaan apliksi di } \\
\text { berbagai hardware dan } \\
\text { softrware yang ada }\end{array}$ & 3,4 & $85 \%$ & $\begin{array}{l}\text { Sangat } \\
\text { praktis }\end{array}$ \\
\hline & Keseluruhan Indikator & 3,46 & $86,41 \%$ & Sangat praktis \\
\hline
\end{tabular}

Tabel 3 dapat digambarkan pada sub indikator (1) penggunaan aplikasi secara bersamaan dikategorikan sangan baik dengan nilai rerata 3,3 dan presentase $82,5 \%$. Hal ini menunjukkan bahwa penggunaan sistem informasi penjualan dapat dilakukan secara bersamaan tanpa menggangu pengguna yang lainnya. Selanjutnya pada sub indikator (2) penggunaan aplikasi mengefisienkan waktu dikategorikan sangat baik dengan nilai rerata 3,45 dan presentase $86,25 \%$. Hal ini menunjukkan bahwa penggunaan sistem informasi penjualan dapat menghemat waktu yang dibutuhkan dalam proses pembelian jauh lebih cepat. Sub indikator (3) penggunaan aplikasi mengefisienkan tempat pembelian dikategorikan sangat baik dengan nilai rerata 3,7 dan presentase $86,25 \%$. Hal ini menunjukkan penggunaan sistem informasi penjualan dapat mengefisienkan tempat pemelian yang sering bertepatan dengan pelanggan yang dadtang ke toko. Sub inikator (4) penggunaan aplikasi di berbagai hardware dan software yang ada dikategorikan sangat baik dengan nilai rerata 3,4 dan presentase $85 \%$. Hal ini menunjukkan penggunaan aplikasi tidak memerlukan spesifikasi khusu untuk di diterapkan dan digunakan.

Tabel 3 menunjukkan bahwa secara keseluruhan indikator memperoleh rerata dengan nilai 3,4 dan presentase $86 \%$ dengan kategori sangat baik sehingga dapat disimpulkan bahwa sistem informasi penjualan siap diterapkan dan digunakan pada Toko Campus Mart UNIMUDA Sorong. Tingkat rerata skor penilaian indikator pengunaan sistem secara praktis pada uji coba kelompok besar dapat dilihat pada Gambar 8. 


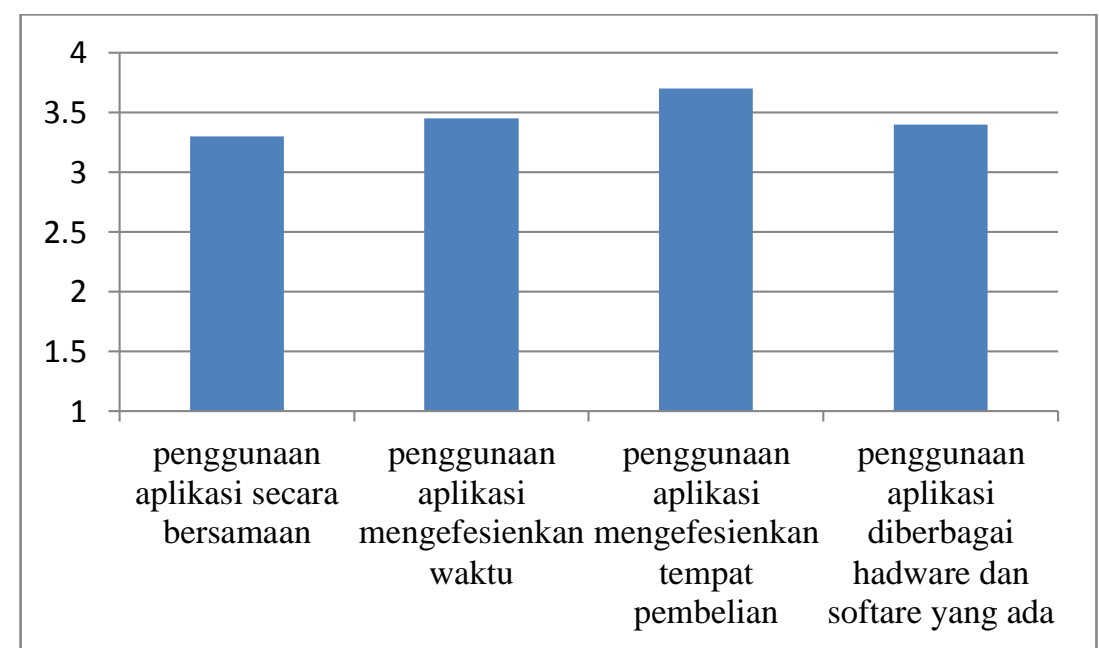

Gambar 8 Grafik Penilaian Penggunaan Sistem Secara Praktis Kelompok Besar

4) Indikator penggunaan aplikasi (efektif)

Tabel 4 Indikator Penggunaan Aplikasi (Efektif)

\begin{tabular}{ccccc}
\hline No & Aspek yang dinilai & Rerata & Presentase & Keterangan \\
\hline $\mathbf{1}$ & $\begin{array}{c}\text { Input/masukan aplikasi } \\
\text { sesuai dengan } \\
\text { output/keluaran }\end{array}$ & 3,45 & $86,25 \%$ & $\begin{array}{c}\text { Sangat } \\
\text { Efektif }\end{array}$ \\
$\mathbf{2}$ & $\begin{array}{c}\text { Tidak terdapat kesalahan } \\
\text { (eror) pada saat aplikasi } \\
\text { dijalankan }\end{array}$ & 3,5 & $87,5 \%$ & $\begin{array}{c}\text { Sangat } \\
\text { Efektif }\end{array}$ \\
$\mathbf{3}$ & $\begin{array}{c}\text { Penginputan atau data yang } \\
\text { dimasukkan diproses } \\
\text { (terselesaikan) }\end{array}$ & 3,3 & $82,5 \%$ & $\begin{array}{c}\text { Sangat } \\
\text { Efektif }\end{array}$ \\
\hline & Keseluruhan Indikator & $\mathbf{3 , 4}$ & $\mathbf{8 5 \%}$ & Sangat Efektif \\
\hline
\end{tabular}

Indikator ini mengukur sistem informasi penjualan yang telah diuji coba penggunaan aplikasi secara praktis siap untuk digunakan. Indikator pada penggunaan aplikasi secara efektif terbagi menjadi 3 sub indikator yaitu: (1) input/masukan aplikasi sesuai dengan output/keluaran, (2) tidak terdapat kesalahan (error) pada saat aplikasi dijalankan dan (3) penginputan data yang dimasukkan di prosees (terselesaikan). Data dari hasil uji coba kelompok besar atau diperluas dapat dilihat pada Tabel. 4

Tabel 4 dapat digambarkan pada sub indikator (1) input/masukan aplikasi sesuai dengan output/keluaran dikategorikan sangat baik dengan nilai rerata 3,45 dan presentase $86,25 \%$. Hal ini menunjukkan bahwa masukan dan keluaran sistem berjalan sesuai dengan proses penjualan. Sub indikator (2) tidak terdapat kesalahan (error) pada saat aplikasi dijalankan dikategorikan sangat baik dengan nilai rerata 3,5 dan presentase $87,5 \%$. Hal ini menunjukkan bahwa sistem informasi seminar tesis tidak terdapat kesalahan atau eror.Sub indikator (3) penginputan atau datayang dimasukkan di proses (terselesaikan) dikategorikan sangat baik dengan nilai rerata 3,3 dan presentase $82,5 \%$. Hal ini menunjukkan bahwa sistem informasi penjualan mampu menerima masukan dan melakukan pemrosesan data dengan baik. 
Tabel 4.16 menunjukkan bahwa secara keseluruhan indikator memperoleh rerata3,4 dan presentase $85 \%$ dengan kategori sangat Efektif. Dapat disimpulkan bahwa sistem informasi penjualan dapat digunakan dengan efektif dalam proses penjualan di Toko Campus Mart UNIMUDA Sorong. Tingkat rerata skor penilaian indikator penggunaan sistem secara efektif pada uji coba kelompok besar dapat dilihat pada Gambar 4.13, dibawah ini:

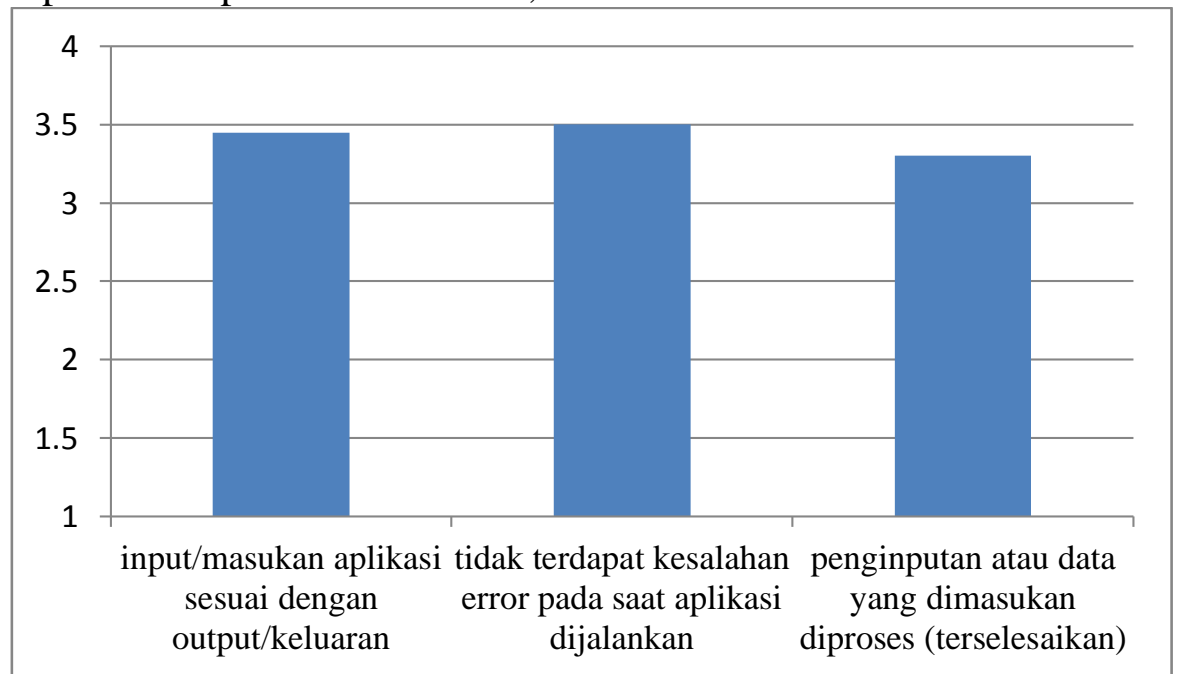

Gambar 4.33 Grafik Penilaian Penggunaan Sistem Secara Efektif Kelompok Besar

5) Indikator Kepuasan Pengguna

Tabel 4.17 Indikator Kepuasan Pengguna

\begin{tabular}{|l|l|l|l|l|}
\hline No & yang dinilai & Rerata & Presentase & Keterangan \\
\hline 1 & $\begin{array}{l}\text { Puas terhadap hasil } \\
\text { aplikasi yang telah } \\
\text { dirancang }\end{array}$ & 3,8 & $95 \%$ & Sangat baik \\
\hline & Keseluruhan Indikator & $\mathbf{3 , 8}$ & $\mathbf{9 5 \%}$ & Sangat baik \\
\hline
\end{tabular}

Tabel 4.17 dapat disimpulkan sub indikator puas terhadap hasil aplikasi yang telah dirancang memperoleh nilai rerata 3,8 dan presentase 95\% dengan kategori sangat baik, hal ini menunjukkan penerapan dan penggunaan sistem informasi penjualan berbasis web berhasil memberikan kepuasan terhadap Pelanggan Toko Campus Mart UNIMUDA Sorong.

6) Indikator Dampak Bagi Toko Campus Mart UNIMUDA Sorong

Tabel 4.18 Indikator Dampak Bagi Toko Campus Mart UNIMUDA Sorong

\begin{tabular}{|l|l|l|l|l|}
\hline No & Aspek yang dinilai & Rerata & Presentase & Keterangan \\
\hline 1 & $\begin{array}{l}\text { Menghemat tenaga, waktu dan } \\
\text { biaya (praktis) }\end{array}$ & 3,8 & $95 \%$ & Sangat baik \\
\hline 2 & $\begin{array}{l}\text { Membantu proses penjualan } \\
\text { toko }\end{array}$ & 3,7 & $91,25 \%$ & Sangat baik \\
\hline & Keseluruhan Indikator & $\mathbf{3 , 8}$ & $\mathbf{8 7 , 5 \%}$ & Sangat baik \\
\hline
\end{tabular}

Berdasarkan Tabel 4.18 maka dapat diuraikan bahwa sub indikator (1) menghemat tenaga, waktu dan biaya (praktis) memperoleh nilai rerata 3,8 dan 
presentase $95 \%$ dengan kategori sangat baik. Selanjutnya untuk sub indikator (2) membantu proses penjualan toko memperoleh nilai rerata 3,7 dan presentase 91,25\% dengan kategori sangat baik. Tingkat rerata skor penilaian indikator dampak bagi Toko Campus Mart UNIMUDA Sorong pada uji coba kelompok besar dapat dilihat pada Gambar 9.

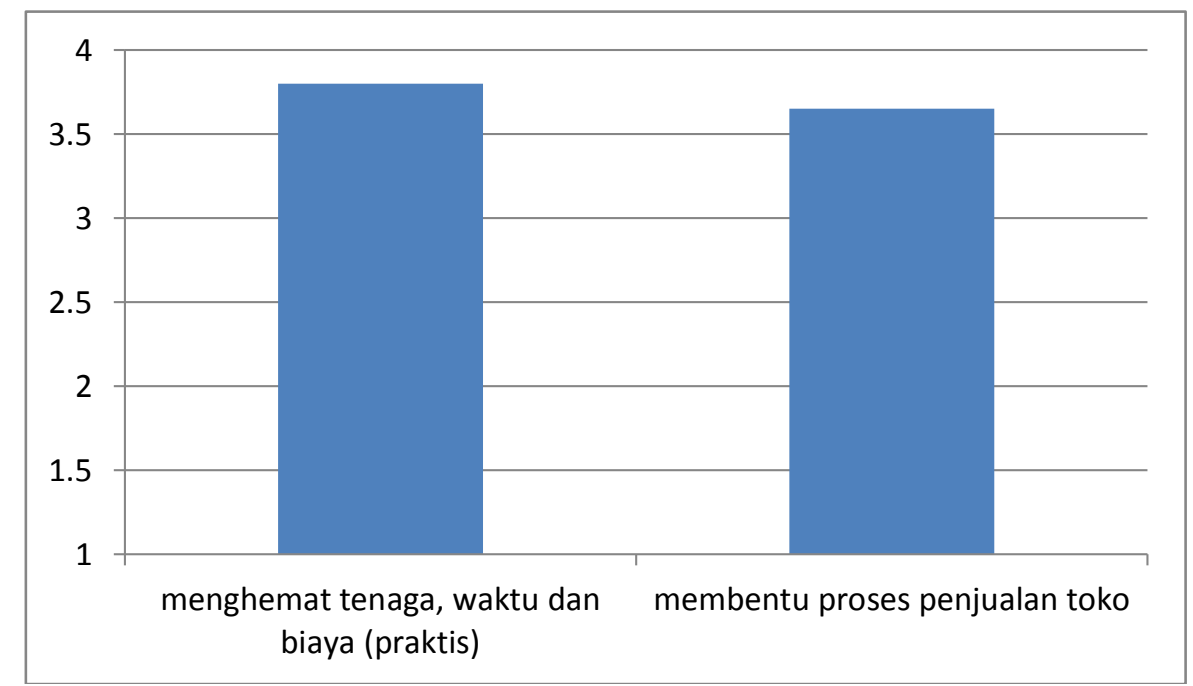

Gambar 9 Grafik Penilaian Dampak Bagi Prodi Kelompok Besar

Dapat simpulkan secara keseluruhan indikator dampak bagi Toko Campus Mart UNIMUDA Sorong berada pada kategori sangat baik dengan rerata 3,8 dan presentase $87,5 \%$. Ini menunjukkan bahwa sistem informasi penjualan yang dierapkan dan yang diuji coba memberikan manfaat bagi Toko Campus Mart UNIMUDA Sorong.

\section{Kesimpulan dan Saran Kesimpulan}

Perancangan Sistem Informasi Penjualan Berbasis Web Pada Toko Campus mart UNIMUDA Sorong dengan PHP dan MySQL telah berhasil dibangun dengan Notepad ++ dan basis data mengunakan MySQL. Sistem ini mampu meberikan informasi produk dari Toko Campus Mart UNIMUDA Sorong kepada user khususnya pelanggan sehingga pengguna mendapatkan kemudahan dalam mencari informasi baru tentang barang yang dijual, selin itu sistem mampu menyediakan penjualan barang yang mana pemesanan produk dapat dilakukan secara online, sehingga pembeli tidak harus datang ke Toko Campus Mart UNIMUDA Sorong.

Berdasarkan seluruh hasil penelitian dapat disimpulkan bahwa indikator aspek program dengan rerata 3,5 dan presentase $87,5 \%$ bahwa aspek program dari sistem informasi penjualan sangat valid, indikator aspek content dengan rerata 3,6 dan presentase $91,25 \%$ bahwa aspek program sangat valid dan indikator aspek pengguna dengan rerata 3,6 dan presentase 87,5 bahwa aspek program sangat valid. Maka aplikasi dapat digunakan atau valid menurut validator untuk diuji coba ketahap berikutnya, berupa uji coba kelompok kecil dan uji coba kelompok besar. Berdasarkan Gambar 4.12 menunjukkan bahwa secara keseluruhan indikator pengguna aplikasi praktis memperoleh rerata dengan nilai 3,4 dan 
presentase $86 \%$ dengan kategori sangat praktis sehingga dapat disimpulkan bahwa sistem informasi penjualan siap diterapkan dan digunakan pada Toko Campus Mart UNIMUDA Sorong dan pada Gambar 4.13 menunjukkan bahwa secara keseluruhan indikator pengguna aplikasi efektif memperoleh rerata3,4 dan presentase $85 \%$ dengan kategori sangat efektif. Dapat disimpulkan bahwa sistem informasi penjualan dapat digunakan dengan efektif dalam proses penjualan di Toko Campus Mart UNIMUDA Sorong.

\section{Daftara Pustaka}

Abdulloh, R. (2016). Web Programming. Jakarta: PT Alex Media Komputindo. Abdulloh, R. (2018). 7 In 1 Pemograman Web Untuk Pemula. Jakarta: PT Alex Mediakoputido.

Anggraeni, E. Y. (2017). Pengantar Sistem Informasi. (E. Risanto, Ed.). yogyakarta.

Azis, S. (2018). Menguasai Php Dan Mysql. (P. Dianing, Ed.). Jakarta: kuncikom. Enterprise, J. (2014). Mysql Untuk Pemula. Jakarta: PT Alex Mediakoputido Enterprise, J. (2017). PHP Komplit. Jakarta: PT Alex Media Komputindo.

Hakim, R. (n.d.). Cara Cerdas Menegelola Blog. Jakarta: PT Alex Media Komputindo.

Hutahaean, J. (2014). Konsep Sistem Informasi. Yogyakarta: CV BUDI UTAMA.

Ramadhani, I. A. (2018). Pengembangan Sistem Informasi Penjadwalan Mata Kuliah Berbasis Web Di Fakultas Teknik Universitas Negeri Makassar. Jurnal Pendidikan, 6(2), 1-15

Josi, A. (2017). Desa ( Studi Kasus Desa Sugihan Kecamatan Rambang ) StmikMusirawas Lubuklinggau, 9(1).

Krisianto, A. (2014). Internet Untuk pemula. Jakarta: PT Alex Media Komputindo.

Kristanto, A. (2018). Perancangan Sistem Informasi Dan Aplikasinya. yogyakarta: Gava Media.

Kurniawan, B. (2008). Desain Web Praktis Dengan CSS. (W. whindy Yoevesstian, Ed.). PT Alex Mediakoputido.

Palevi, A. R. (2013). Analisis Dan P Erancangan Sistem Informasi Penerimaan Peserta Didik Baru Berbasis Website Pada Smp Negeri 2 Mojosongo Pendahuluan Landasan Teori \& Tinjauan Umum. Ilmiah DASI, 14(04), 2-7.

Raharjo, B. (2016). Modul Pemograman Web. Bandung: Modula.

Ramadhan, F. (2018). Sistem Informasi Penjualan Berbasis Web, 5, 43-57.

Randi. (2015). Rancangan Sistem Informasi Keuangan Gereja Berbasis Web Di Jemaat GMIM Bukit Moria Malalayang. Teknik Elektro Dan Komputer, 4(7), $1-7$.

Rerung, R. R. (2018). Pemograman Web Dasar. Yogyakarta: CV Budi Utama.

K. Sandy \& Y. I. D. A. Eka , "Penerapan Rapid Application Development Pada Sistem Penjualan Sepeda Online," Jurnal SIMETRIS , Vol. 6 No. 1, ISSN No. 2252-4983 hlm. 29, 2016.

Hutahaean Jeperson, Konsep Sistem Informasi, Grup Penerbitan CV BUDI UTAMA, 2014

Brtha Sidik, Ir, Pemrograman Web dengan PHP, Informatika Bandung, 2012

Yessy Fadillah, Sistem Informasi Penjualan Kerupuk Berbasis Web Rersponsive, 
Jurnal Sistem Informasi UD. Sumber Makmur, Teknologi Informatika dan Komputer Volume 8, Nomor 1 (2017), ISSN 2089-0265

Ikhtiar Rizki, Pembutan Sistem Informasi Penjualan Berbasis Web, Toko Ali computer, Jurusan Teknik Elektro Universitas Lampung J1. Prof. Sumantri Brojonegoro No.1 Bandar Lampung 35145, Volume 8, No. 1, Januari 2014

Farhan Ramadhan, Sistem Informasi Penjualan Berbasis Web, PT Mustika Jati, Kalbiscentia,Volume 5 No. 1 Februari 2018

Wardana. Aplikasi Website Perfesional dengan PHP dan Query. (2016). Jakarta: PT Elex Media Komputindo.

Hasanah Uswatun. Sistem Informasi Penjualan On_Line pada Yoko Kreatif Suncom Pacitan. IJNS-Indonesian Journal on Networking and Security. 2013; vol.2 (no.4): halaman $40-48$.

Sri Mulyani. Metode Analisis dan Perancangan. Bandung: (2016). Abdi Sistematika. 